\title{
Teacher Evaluation Policies in Albania
}

\author{
Klodiana Leka \\ Ph.D. candidate, University “Aleksandër Moisiu”, Durrës; klodial@gmail.com
}

\section{Doi:10.5901/ajis.2016.v5n2p145}

\begin{abstract}
This paper is focused on the overall purpose of the evaluation of teachers and on the teachers' evaluation policies in Albania. Evaluation purpose is to protect and improve the quality of teaching, so that boards should ensure a process that allows and encourages supervisors and teachers collaboration to improve teaching practices in the classroom. Developing high-quality professionals should be available for every teacher. Professional development programs should be based on state standards, the district where the school is located, learning goals and the identified needs of students and teachers. In addition, all new teachers must have objective support and participate in an introductory and counselling program. Evaluation of teachers tends to influence professional development and career decisions. The literature suggests that assessment strategies are used by objective. If the objective is the responsibility, there should be used summative strategies; if the objective is professional growth, there should be used formative strategies. According to the Institute of Education Development in Albania, professional standards for teachers are part of a broader framework of documents involving all education system. Teacher evaluation tests are performed only in Tirana from evaluation tests commissions. From this paper it is seen that there is lack of a comprehensive policy for the development of teaching profession and teacher evaluation systems in Albania which lack theoretical foundation. Likewise, there is lack of studies, national estimates on the basis of which would have drawn up policies and would be taken better decisions for teachers.
\end{abstract}

Keywords: evaluation, professional development, evaluation policies, professional standards, evaluation systems

\section{Introduction}

Teacher evaluation is a complex process, a series of activities and actions interconnected with a special purpose. Because of the fact that teachers deal with complex problems, they should be regarded as professionals, which means that their standards should be developed by their colleagues and that their evaluation should be concentrated on the level they solve their professional problems with the proper competence (Soar, Medley, DK Coker, 1983). Their evaluation should emphasize more their teaching and not them as individuals, and should be taken into consideration inclusion and reaction of others dealing with education process ((Fullan with Stiegelbauer, 1991).

Evaluation process usually includes preparation, observation, data collection, reporting and conclusion. Data collection basically requires a formal observation which is prior to a pre-conference and then followed by a postconference. Using formal observations does not mean to ignore informal ones. Unexpected visits are shown to be more effective than notified visits. However, this method has some limits. DarlinB-Hammond, Wise, \& Pease (1983) explain that unexpected visits do not show much about coherence, depth and length of content of the curricula, used techniques in teaching, quality and variability of used materials, types and frequency of homework, quality of tools used in assessing students or their adaptability on special students in the classroom context as a whole (pg. 158). Clark (1993) pointed out that, teacher evaluation should be part, although small, but important of strategies in improving the. These evaluations should be more in the form of dialogues than based on hierarchy. The work share should be set between those who decide what, when and how it is going to be taught, and those who teach, because the curricula and teaching strategies are in a direct opposition with treating teachers as professionals. Evaluators should know subjects, pedagogical and class characteristics of the teachers under evaluation. Also, evaluators should consider the fact that experienced teachers and excellent teachers are so able in their pedagogical performance as whether education theory or research theory cannot explain and predict (Shulman, 1987). These innovative people taking such a risk, instead of being discouraged, should be encouraged. That is why each effort to set teaching standards and their functioning in evaluation must go beyond experts' judgment. Consequently, there is the need for an evaluation form that reflects a brighter view of teaching for teachers to be inspired to increase their level, while curricula and their programs are being created and designed to be implemented in supervised schools, by introducing new forms of monitoring, cooperation and collegiality (Shulman, 1987, p. 44).

There are three main approaches to evaluate teachers who show average validity to signal efficiency: classroom 
observations by colleagues, managers or external evaluators, models that assess students' achievements and assessments from students. While other approaches like executives or directors judgment, self-reports of teachers and teacher portfolio analysis are limited evidence.

Successful teacher observations are used mainly as a formative process, as a development tool for reflective creation run by teachers themselves in the role of students toward a big gamma of assessments or appraisals. Protocols of high-quality surveillance include observers who are trained especially for this training. Models that assess students' achievements depend on the availability of good results, which may be sensitive to any arbitrary essential choice in order to decide which variables should be included and what assumptions underpin models. Respective teacher effectiveness estimates are moderately stable from year to year and from classroom to classroom.

Collection of student assessments should be a free and simple source of a good feedback about teaching behaviour from a wide range of observers who can draw output from many teaching classes.

\section{General and Specific Professional Teachers'standards in Albania}

According to IZHA (2010) - the Institute of Education Development, professional standards for teachers are part of a broader framework of documents involving all education system. This includes standards for school principal, coach, mentor, pedagogical deputy director, etc. Designing of teacher professional standards aims at professionalizing teaching. This means considering teaching as a profession to be standardized just like the other professions, being in harmony with other social partners and interest groups.

General teacher basic standards describe professional characteristics to be met by every teacher who has passed the initial stage and is licensed as such. If the teacher intends to gain a higher qualification level as a specialist teacher, master, etc., the teacher must meet complementary standards in each of these professional career stages ((IZHA,2010), point $1 / 1-2$ ).

Besides the general standards, the teacher must meet specific standards related to the object of his/her work. Meeting these standards is verified through an external evaluation, determined by means of orders and special instructions. Teachers' salaries for each career ladder are also set through laws and/or legislation. Standards will help teachers identify the needs for their professional development, and identify areas in which they are capable, as well as areas that need further development ((IZHA, 2010, point 1/ 1-5, 7).

Standards are used by professional teacher organizations to make licensing of teachers, assessment and their punishment, as well as to provide to the interested people relevant professional support; from agencies that accredit training and assessment centres, for teachers, as well as for those that accredit training programs; from training and qualification teacher centres which analyse the needs of teachers and coordinate the support of teachers with training and professional and educational materials; from the drafters of initial training curricula of teachers and institutions involved in such training; the drafters of legal documents and instructive acts, dealing with teachers; the drafters of teacher qualifying programs, with different seniority in teaching; community of parents and all stakeholders, considered as education partners. All teachers, regardless of the institution they work in, public or non-public schools, are eligible to register to obtain the levels of qualification (IZHA, 2010), point 1/8 and 9).

According to IZHA (2010), general basic standards for the teacher are:

Standard 1: Relations with children and young people

Standard 2: Updating

Standard 3: Communication, teamwork and cooperation

Standard 4: Individual professional development

Standard 5: Curricula

Standard 6: Students achievements and their diversity

Standard 7: Health and continuity

Standard 8: Planning

Standard 9: Teaching

Standard 10: Assessment, monitoring and results

Standard 11: Reflection on teaching and learning

Standard 12: The learning environment in the classroom 


\section{Professional Development and Training Programmes}

The purpose of professional development of educational workers (director, deputy director, teacher) is the updating of knowledge and the development of their competencies, in order to ensure to all students quality education service (Udhëzimi nr. 26, datë 15.08.2014 "'Për Zhvillimin Profesional të Punonjësve Arsimor", Chapter 1, Article 1). Internal development is carried out at professional educational institution by the council of teachers and subject teams, whereas, professional development forms of educational workers are internal professional development, training, professional networking, counselling, short-term and long-term courses. A day of training consists of six hours, which is three hours by coach or training material study program / module of the trainee and three hours of individual work in preparing tasks. A day of training is reflected with two credits in the certificate of trainees, while an employee education must earn at least six credits during the school year (Udhëzimi nr. 26, datë 15.08.2014 "'Për Zhvillimin Profesional të Punonjësve Arsimor", Chapter 1 , Article $3,4,6)$. Trainings are held on the basis of the study "The advantages of professional development of educational workers," which is prepared by IZHA every two years and is based on teachers general standards, principal standards, needs for professional development identified by IZHA, recommendations compiled every two years by the General Directorate of Pre-University Education in the Ministry of Education and Sports (MoES), National Exams Agency (NEA), State Inspectorate of Education (SIE), IZHA, DAR / ZA and training agencies by their initiative. Education Development Institute (IZHA), every two years, develops questionnaire to identify needs for professional development of workers in education and on the basis of the study "The advantages of professional development of educational workers", IZHA designs, every two years, the document "Announcement of interest for training educational workers" that contains a number of programs / modules offered to training agencies, also, to be selected for training educational workers. "The announcement of interest for training educational workers" is approved by MAS and published on the website of MoES and IZHA (Instruction no. 26, dated 15.08.2014 "On Professional Development for Educational Workers ", Chapter 1, Article 7).

By Order of the Minister in any calendar year period, IZHA declares interest to other training topics according to reforms cases (Instruction no. 26, dated 15.08.2014 "On Professional Development for Educational Workers", Chapter III, Article 13 / 1). Modules assessment is made by IZHA, which declares every two years, in September, the request for modules evaluator. The candidate for evaluator submits his/her CV to the secretariat of KAT, and he/she may be a teacher or specialist possessing sufficient knowledge of the module, testified in his/her CV rated "excellent" or "very good" in the last exam of qualification; Director of an educational institution rated at least "good" by NEI national education inspector, within the last four years of school or the school he/she runs is one of successful schools in one of the last two school years. The Secretariat shall prepare assessors for assessment procedure training modules and organize evaluation activities. A training module is assessed by two people who initially assess the module being in different environments, then compare together estimates to reach a single estimate (Udhëzimi nr. 26, datë 15.08.2014 "'"Për Zhvillimin Profesional të Punonjësve Arsimor", Chapter IV, Article 19 and 21).

After the selection of the Agency under the procedures provided in Instruction no. 26; dated 15.08.2014, "On Professional Development for Educational Workers ", accredited training agency for a program/training module directly sends one month prior to training directly, by email to DAR/ZA offering training, the secretariat and NEI, training dates the agency offers, topics and expected results of the program / training module and predicted data. DAR / ZA notify principals of educational institutions by email or letter benefiting from training and organize a meeting with them.

Principals of institutions benefiting from direct training notify each employee of the educational institution, the data provided and IZHA publishes training annual data on its website. Educational employee selects programs / modules directly accredited. In special cases, the directorate, after receiving the opinion of the Council of Teachers, sets out the criteria for the appointment of teachers to be trained by an agency for a training program / module. The principal of the educational institution for educational workers of the institution or DAR / ZA for educational staff in the jurisdiction, notifies by e-mail the relevant agency for the participation in a relevant program / module of educational workers. Training agency notifies the principal of the educational institution about the date and time of the direct training sessions (Udhëzimi nr. 26, datë 15.08.2014 "'"Për Zhvillimin Profesional të Punonjësve Arsimor", Chapter VI, Article 26, 27).

The number of participants in a direct training session is not more than 25 , excluding cases where the only method of training is the lecturing, trainings are held without interrupting the lecture. The training agency decides if whether a trainee will submit or not the exam based on the profile content and attending classes of the trainee when the training is direct (not less than $90 \%$ of classes in the module). The testing is done in writing, but the training agency has the right to develop verbal testing with all participants or some of them. Test papers with answers of the trainees are saved for a year from the date of training and are object to inspection by ISHA. The certificate of a module is given to an educational 
worker when he/she has accumulated at least $75 \%$ of points. The certificate labels the program/module and the respective credits number. Training agencies submit to the secretariat the list of certified workers by this agency for every accredited module. Monitoring and assessment of training sessions is done by MAS, IZHA and DAR/ZA in their jurisdiction. Isha inspects training sessions (Udhëzimi nr. 26; dt: 15.08.2014, "Për Zhvillimin Profesional të Punonjësve Arsimor", Kreu VII, Neni 28/2, 3; Neni 29/4, 6; Neni 30/4; Neni 31/1, 2, 6; Kreu VIII, Neni 32).

Besides the program/module trainings, there are also short-term courses which are provided as informative sessions organized by IZHA, AKP and IShA, with DAR/ZA specialists and educational workers about innovations in educational reforms, new legislation acts of the Minister of MofES and these institutions instructions. The credits of shortterm courses are determined by KAT. The same happens with the short-term courses organized by DAR/ZA, where the educational workers taking part undergo an exam and are certified by the principal of DAR/ZA (Udhëzimin nr. 26; dt: 15.08.2014, "Për Zhvillimin Profesional të Punonjësve Arsimor", Kreu X, Neni 34, 35).

For the development of workers in educational institutions, there is also the professional network which aims the professional growth through exchange of experience and opinions of its members about their daily work practices. There are not more than 20 workers in a professional network (principals or teachers of elementary school, teachers of the same subject in the same educational level, teachers of the same learning field in the same educational level, tutoring teachers). In every network meeting there is a developed topic about daily work practices which is planned by the runners of the network in collaboration with its members. During a school year, a member, according to his/her role, can take part once, frequently or regularly (this is determined by DAR/ZA). DAR/ZA organize a certain number of networks based on its priorities and observe meetings of networks assessing their quality (Udhëzimi nr. 26; dt: 15.08.2014, "Për Zhvillimin Profesional të Punonjësve Arsimor", Kreu XI, Neni 36, 37, 38, 39).

DAR/ZA plan and organise educational workers counselling about daily practice issues of managing educational institution and students teaching. The counselling is accomplished according to a calendar set by the principal of DAR/ZA in its settings or in the settings of an educational institutions, by the specialists of DAR/ZA or educational workers selected by it; through letters sent to educational institutions (Udhëzimi nr. 26; dt: 15.08.2014, "Për Zhvillimin Profesional të Punonjësve Arsimor", Kreu XII, Neni 41).

From 2014 and on, teachers who have done at least three days training a year, have the right to win the category of teacher qualification, where a day of training lasts 8 hours of professional development from which two hours are training sessions, and the other hours are individual works or group works to prepare topic tasks, case studies, projects, essays, etc. Three training days in a calendar year are equal to one credit (Udhëzimin Nr. 2, Dt: 05.02.2014, "Për Kriteret dhe Proçedurat e Kualifikimit të Mësuesve", Neni 1).

\section{Policies of Teacher Qualification in Albania}

Qualification of teachers in pre-university educational system is ran by the Directorate of Internal Services in MAS, is organized and administered by the Institute of Education Development (IZHA) and DAR/ZA. This process is conducted through personal portfolio of professional teacher development and tests according the respective profiles. Personal portfolio of the candidate contains Curriculum Vitae (with pictures), notarized copy of the certificate with credits, notarized copy of verified titles / scientific degrees (if any), and notarized copy of foreign language certificate (if any). Professional portfolio consists of a comprehensive plan of activities with students of a particular class, within the school as a community centre, a test of a given subject chapter, objectives and achievements of students in a chapter (in a particular subject and class), a model of a lesson plan (journal), and a plan of a curriculum project along with a description of its realization. Portfolio Assessment Commission (PAC), established by the head of DAR / ZA estimates by 1-3 points each component of professional portfolio, according to criteria established by instruction from the IZHA. The candidate, who doesn't win at least five points for the portfolio or does not submit at least one component of the portfolio, does not participate in the qualification test.

The candidate earns five bonus points if he/she has a diploma: (SHPU, MND, above 60 ECTS Master, Doctorate) acquired in the field of teaching, for teachers who have graduated before January 2011 and certified by a state exam for diplomas after January 2011. Master diploma does not receive bonus points if it is a school criterion for the profession of teacher; the foreign language certified by the Faculty of Foreign Languages at the University of Tirana, for teachers who have graduated before 2010 or internationally recognized tests; If the teacher has got at least 7 points in each of the qualification year from the list of accredited programmes (Udhëzimin Nr. 2, Dt: 05.02.2014, "Për Kriteret dhe Proçedurat e Kualifikimit të Mësuesve", Neni 2, 4).

Qualification tests are developed by selecting from the appropriate question group which is roughly five times the 
corresponding test questions. Funds of questions and tests raised are compiled by the leaders of IZHA, consisting of specialist and teachers under the respective profiles, who sign a contract with the director of IZHA. Qualification exam test consists of two parts. The first part contains the official documents relating to the activity of teachers, relevant subject programs, the methodology of teaching and learning in general and the subject, ethics and communication of teachers in the educational institution, ways of spelling the Albanian language, and other designated areas by the Minister.

The second part involves the scientific content of the subject according to the appropriate qualification program. Secretion of tests is done via bar codes. In each test there is a certain place for the bar code. Secretion tests begins immediately after starting the exam development process. The process of secretion of tests is carried out by the administrator of secretion. The person who does the secretion places the bar code on the test and on the list of names of candidates prepared by IZHA, (2014) and the candidate signs after having verified the name on the list (Section 5 / II, III, VII).

Evaluation of tests is performed in Tirana from evaluation tests commissions. The assessor signs the contract with the director of IZHA. A test is evaluated by a group of two people: a specialist from IZHA or its accomplice, and a teacher of the subject being tested. The Commission estimates the points in each of the two parts of the test and specifies alleged copying tests. The final assessment of the candidate is done with 100 points system which consists of portfolio scores, bonuses of the first half and second half. The candidate is evaluated with five levels: A, B, C, D, E corresponding to assessment with the words "excellent"; "very good"; "good"; "sufficient" and "weak".

The candidate does not win the final qualification if the rating is $E$ ("poor"), in cases when there aren't even minimal points gained in at least one of the two parts of the test. The candidate who wins the category of qualification, is provided with a certificate which indicates the evaluation letter accompanied in words. Candidates who do not receive the training course as a disciplinary measure, are eligible to apply for qualification not earlier than two years (Udhëzim i MAS Nr.2, datë 05.02.2014 "Për kriteret dhe procedurat e kualifikimit të mësuesve", Article 5 / VIII, X, Article 6/4).

Within five days of portfolio evaluation, the candidate has the right to appeal the assessment, by means of writing, to the head of the DAR / ZA, which sends the applicant a written response within five days of the complaint submission. The head is the ultimate answer. Within five days from the day of the exam, the candidate has the right to appeal in writing to the director of IZHA about irregularities during the exam or penalties that have been given by the manager or head of administration of the exam. IZHA leader sends the applicant a written response within ten days from the date of complaint submission. This decision is final. Within five days of notification by DAR / ZA for the evaluation of the exam the candidate has the right to appeal in writing to the director of IZHA about the assessment.

Chairman of the relevant committee of Test Review in IZHA sends to the applicant the written response within ten days of receiving the complaint. If the complaint submission is deemed right, applicant's test is reassessed. Test review Commission's decision is final (Instruction Nr. 2, dated 05.02.2014, "On the Qualification Criteria and Procedures of Teachers", Article 7). It is not allowed that drafters of questions fund be also authors of textbooks of students, authors of helping books for students or teachers (except those published by the central dependence institutions of MAS), candidates for the qualification of that year. Drafter of the test, the assessor of the test, the head of administration of the exam, administrator, secretor, authorized person, the member of the committee of the reviewing tests should not have family relations with candidates (husband / wife, parent, brother / sister, child, adults, parents of husband / wife). Based on the final results of the candidates, Internal Services Directorate in MAS, sends to educational local entities a letter for the wage supplement (Instruction Nr. 2, dated 05.02.2014, "On the Qualification Criteria and Procedures of Teachers" Article 8,9$)$.

\section{Conclusion}

The creation of a supportive legislation for the profession of teachers has helped in developing teacher's profession. In the last decade (2004-2014), Assembly and Government of Albania have approved laws and legislation acts, which have had an impact in developing education in general as well as the teaching profession, by supporting changes in education system and by enhancing opportunities for students and teacher's status. Including teaching into regulated professions is a positive step expected to guarantee a better quality of teachers. Teachers' training schemes have changed by setting programmes, required credits and criteria, and by liberalizing training market. The growth of numbers of teachers with higher education is a positive trend for a better quality of teachers. There is also a lack of research, assessment and complete data which enable a thorough information impacting into legislation, education policy and teachers status.

There is lack of a comprehensive policy for the development of teaching profession and teacher evaluation systems in Albania lack theoretical foundation. Likewise, there is lack of studies, national estimates on the basis of which 
would have drawn up policies and would be taken better decisions for teachers. Country is still very involved in teacher evaluation system. The most problematic is the system of evaluating the performance of teachers which is a responsibility of the school. Policies undertaken so far by the Ministry of Education, have reformed teacher preparation system by changing the structure of the curriculum, but failed to approximate the curriculum of institutions of higher education because of the different approaches that they have selected. The number of teachers in pre-school and secondary education has increased, while the number of teachers in primary education has declined. It is noted that there is a lack of gender balance in staff employed in the education system.

Most teachers in primary and secondary education are women and that no man is employed in preschool. Incoming quality of students preparing to be teachers is very low for some 20 years, while the average score of students in entry is from 5-7, compared with other branches where it is required a higher average to start university. The relationship between universities and schools during the period of professional practice is not regulated by any regulatory documents and supervision of practice and its evaluation is associated with numerous problems. The mentoring system for professional practice is weak and does not work. Publication of data and results of the evaluation of teachers is almost non-existent (Haxhiymeri \& Mita, 2014).

\section{References}

Clark, D. (1993). Teacher evaluation: A review of the literature with implications for educators. Unpublished Seminar Paper, California State University at Long Beach.

Darling-Hammond, L., Wise, A. E., Pease, S. R. (1983). Teacher evaluation in the organizational context: A review of the literature. Review of Educational Research, 53(3), 285-328.

Fullan, M., with Stiegelbauer, S. (1991). The new meaning of educational change. New York: Teacher's College Press.

Haxhiymeri E., Mita N., Zhvillimi Profesional dhe Vlerësimi i Mësuesve në Shqipëri, Koalicioni për Arsimin e Fëmijëve në Shqipëri, Tiranë 2014.

Soar, R.S., Medley, D.M. \& Coker, H. (1983). Teacher evaluation: A critique of currently used methods. Phi Delta Kappan, 65, $239-246$.

Shulman, S., Lee (1987). Knowledge and Teaching: Foundations of the New Reform. Harvard Educational Review, Volume. 57, No 1, February 1987

IZHA (2010) Standardet e Përgjithshme të Mësuesit, 2010.

Udhëzimi nr. 26; dt: 15.08.2014, "Për Zhvillimin Profesional të Punonjësve Arsimor"

Udhëzim i MAS Nr.2, datë 05.02.2014 "Për kriteret dhe procedurat e kualifikimit të mësuesve". 